\title{
Diversity and enzyme production by yeasts isolated from raw milk in Southern Brazil
}

\author{
Diversidade e produção de enzimas por leveduras isoladas de leite in natura no Sul do Brasil
}

\author{
Andréia Spanamberg ${ }^{1}$, Claudia Hartfelder ${ }^{1}$, Alexandre Meneghello Fuentefria ${ }^{2} \&$ Patrícia Valente $^{2,3}$
}

\begin{abstract}
Raw milk is generally considered an ideal environment for the growth of many microorganisms because of its nutrient richness. Although there have been numerous reports on the occurrence of yeasts in dairy products in the world, few have attempted to determine the diversity of these microorganisms in samples from raw milk, mainly in Brazil. Thirty six samples were collected from 25 dairy farms located at different districts of Rio Grande do Sul, during a period of 5 months. A total of 80 isolates were obtained and identified according to standard methods. Of these, 63 strains corresponded to true yeasts (51 with ascomycetic and 12 with basidiomycetic affinity), and 17 isolates were recognized as yeast-like strains. Yeast distribution was uneven among the producers analyzed. The most frequent yeasts isolated in this study belong to the genera Kluyveromyces, Rhodotorula, Candida, Geotrichum, and Trichosporon. The high frequency of isolation of Geotrichum and Trichosporon from raw milk is of great concern. Almost $79 \%$ of our isolates were lipolytic, while only $6 \%$ were proteolytic. Although these microorganisms are not expected to survive the pasteurization/sterilization treatments applied during milk processing, their enzymatic activities may alter milk constituents and affect its quality.
\end{abstract}

Key words: yeast identification, cow's raw milk, lipase, protease, milk quality.

\section{RESUMO}

O leite in natura é geralmente considerado um meio ideal para o crescimento de muitos microorganismos devido a sua riqueza nutritiva. Apesar de haver numerosos relatos da ocorrência de leveduras em produtos lácteos em todo o mundo, poucos tentaram determinar a diversidade desses microorganismos em amostras de leite in natura, principalmente no Brasil. Trinta e seis amostras foram coletadas de vinte e cinco produtores localizados em diferentes municípios do Rio Grande do Sul, durante um período de cinco meses. Um total de oitenta isolados foram obtidos e identificados de acordo com a metodologia convencional. Desses, 63 cepas corresponderam a leveduras verdadeiras ( 51 com afinidade ascomicética e 12 com basidiomicética) e 17 isolados foram reconhecidos como fungos semelhantes a leveduras. A distribuição das leveduras foi desigual entre os produtores analisados. As leveduras mais freqüentes isoladas neste estudo pertencem aos gêneros Kluyveromyces, Rhodotorula, Candida, Geotrichum e Trichosporon. A alta frequência de isolamento de Geotrichum e Trichosporon a partir do leite in natura é preocupante. Cerca de $79 \%$ dos nossos isolados foram lipolíticos, enquanto apenas $6 \%$ foram proteolíticos. Apesar de não ser esperado que esses microorganismos sobrevivam aos tratamentos de pasteurização / esterilização empregados durante o processamento do leite, sua atividade enzimática pode alterar os constituintes do leite e afetar sua qualidade.

Descritores: identificação de leveduras, leite bovino in natura, lipase, protease, qualidade do leite. 


\section{INTRODUCTION}

Raw milk is generally considered an ideal environment for the growth of many microorganisms because of its nutrient richness. Contamination of raw milk can take place during milking, handling, storage, and other pre-processing activities. Information on the microbial diversity of raw milk can be used to judge its sanitary quality and the conditions of production $[5,14]$. Yeasts can have a negative action as spoilage microorganisms in dairy products, such as cheese, besides being able of causing several infections in man and animals $[8,10,12,16]$. Milk quality can also be affected by the enzymes produced by contaminating microorganisms [15]. The most important of these are proteases and lipases [4]. On the other hand, yeasts isolated from raw milk have been used as starter cultures in dairy products such as cheese [6]. A starter culture can provide particular characteristics in a more controlled and predictable fermentation. These yeasts may also show a beneficial effect on the quality of dairy products because they may inhibit or eliminate undesired microorganisms and contribute to the maturation process by supporting the function of the starter culture [2,9].

Although there have been numerous reports on the occurrence of yeast in dairy products in the world, few have attempted to determine the diversity of yeast and yeast-like fungi in samples from raw milk, mainly in Brazil. The aim of this work was to verify the diversity of species of yeast and yeast-like isolates from raw milk collected in 25 dairy farms from five different districts in southern Brazil.

\section{MATERIALS AND METHODS}

\section{Milk samples}

The study was carried out on 36 raw milk samples collected from 25 dairy farms located at different districts of Rio Grande do Sul (Cachoeirinha, Glorinha, Gravataí, Esteio and Viamão), during a period of 5 months. Producers 01, 07, 12, 14, 21, 26, 33 and 37 were sampled twice, while producer 29 was sampled three times during this period. Twenty five milliliters of milk from each dairy farm were aseptically collected from a churn into a sterile glass bottle, transported to the laboratory under refrigerated conditions, and analyzed immediately.
Isolation and identification of yeast and yeast-like fungi

Aliquots of $0.1 \mathrm{~mL}$ of serial dilutions were spread in triplicate on acidified YM agar medium (1\% glucose, $0.3 \%$ malt extract, $0.3 \%$ yeast extract, $0.5 \%$ peptone, $2 \%$ agar, $400 \mathrm{mg} / \mathrm{L}$ of chloramphenicol, $\mathrm{pH} 4.5$ ) or acidified YEPG agar medium ( $0,5 \%$ yeast extract, $2 \%$ glucose, $1 \%$ peptone, $2 \%$ agar, $400 \mathrm{mg} / \mathrm{L}$ of chloramphenicol, $\mathrm{pH} 4.5$ ). After incubation at $22^{\circ} \mathrm{C}$ for 2-4 days, representative colonies of each morphological type were isolated and purified in Petri dishes containing YEPG medium. The strains were maintained in GYMP $(0.5 \%$ glucose, $2 \%$ malt extract, $0.5 \%$ yeast extract, $0.2 \%$ monobasic sodium phosphate, $2 \%$ agar) slants covered with a layer of sterile mineral oil, and kept in the refrigerator. The isolates were phenotypically characterized by standard tests $[1,11,17]$. Identification was performed according to Barnett et al. [1] and the computer program YEASTCOMPARE (C. Ciriello and M.A. Lachance, Copyright @ 1999-2001).

\section{Enzyme assay}

For determination of proteolytic and lipolytic activity, the strains were previously grown on YEPG agar at $22^{\circ} \mathrm{C}$ for $24 \mathrm{~h}$, diluted in sterile distilled water to about $4 \times 10^{5}$ cells $/ \mathrm{mL}$, incubated for another $24 \mathrm{~h}$, and used to inoculate the solidified agar surface of pre-poured plates or the tubes containing liquid medium. Protease production was tested by inoculation on Casein Agar ( $0.67 \%$ yeast nitrogen base, $0.5 \%$ glucose, $0.5 \%$ casein and $2 \%$ agar), adjusted to $\mathrm{pH} 7.0$ with $5 \mathrm{~N} \mathrm{KOH}$, and incubation at $22^{\circ} \mathrm{C}$ for 7 days. After precipitation with $1 \mathrm{M} \mathrm{HCl}$, protease production was indicated by the presence of a clear zone around the colonies [3]. Lipase production was tested in tubes containing $0.67 \%$ of yeast nitrogen base plus $0.5 \%$ tween 20 (polyoxyethylene sorbitan monolaureate 20) as the sole carbon source. The strains were incubated at $22^{\circ} \mathrm{C}$ for 21 days and the enzymatic activity was indicated by yeast growth in the tubes. The level of enzyme production was evaluated by the halo diameter in solid media, measured in centimeters, or by turbidity in liquid media. Positive results were repeated for confirmation. No discrepant results were found in repeated experiments. 
Spanamberg A., Hartfelder C., Fuentefria A.M. \& Valente P.2004. Diversity and enzyme production by yeasts isolated from raw milk in Southern Brazil.

Acta Scientiae Veterinariae. 32:195-199.

Box 1. Frequencies of yeasts isolated from raw milk samples collected from 25 dairy farms located at several districts of Rio Grande do Sul, during a period of 5 months *.

\begin{tabular}{|c|c|c|c|c|c|c|c|c|c|c|c|c|c|c|c|c|c|c|c|c|c|c|c|c|}
\hline DAIRY FARMS & 01 & 02 & 04 & 07 & 08 & 10 & 11 & 12 & 13 & 14 & 18 & 19 & 21 & 22 & 23 & 26 & 27 & 29 & 32 & 33 & 34 & 36 & 37 & 38 \\
\hline${ }^{a}$ Candida a aseri & & & & & & & & & & & & & & & ${ }^{\mathrm{b}} 1$ & & & & & & & & & \\
\hline Candida aaseri-like & & & & & & & & & & & & & & & & & & & & & & 1 & & \\
\hline Candida auringiensis & & & & & & & & & & & & & & & & & 1 & & & & & & & \\
\hline Candida colliculosa & & & & & & & & & & & & & & & & & 1 & & & & & & & \\
\hline Candida bertae & & & & & & & & & & & & & 1 & & & & & & & & & & 1 & \\
\hline Candida drosophilae & & & & & & & & 1 & & & & & & & & & & 1 & & & & & & \\
\hline Candida intermedia & & & & & & 1 & 1 & & & & & & & & & & & & & & & & & \\
\hline Candida insectalens & & & & & & & & & & & & 1 & & & & & & & & & & & & \\
\hline Candida insectalens-like & & & & & & & & & & & & & & & & & & & 1 & & & & & \\
\hline Candida maltosa & & & & & & & & & & & & & & & & & & & & & & & & 1 \\
\hline Candida montana & & & & & & & & & & & & & & & & & & & & & & 1 & & \\
\hline Candida mucifera-like & & & & & & 1 & & & & & & & & & & & & & & & & & & \\
\hline Candida pararugosa & & & & & & & & & & & & & & & & & & & & & & & 2 & \\
\hline Candida magnoliae & & & & & & & & & & & & & & & & & & & & & & & 1 & \\
\hline Candida restingae-like & & & & & & & & & & & & & & & 1 & & & & & & & & & \\
\hline Candida spp. & 1 & & & & & 1 & 1 & 1 & 1 & & & & & & & & 1 & 1 & & 1 & & 1 & 1 & 1 \\
\hline Candida sake & & & & & & & & & & 1 & & & & & & & & & & & & & & \\
\hline Candida sorbophila & & & & & & & & & & & & & 1 & & & & & 1 & & & & & & \\
\hline Candida robusta & & & & & & & & & & & & & & & & & & & & & & & 1 & \\
\hline Cryptococcus curvatus & 1 & & & & 1 & & & & & & & & & & & & & & & & & & & \\
\hline Cryptococcus sp. & & & & 1 & & & & & & & & & & & & & & & & & & & 1 & \\
\hline Debaryomyces hansenii & & & & & & & & & & & & & & & & 1 & & & & & & & 1 & \\
\hline Debaryomyces melissophilus & & & & & & & & 1 & & & & & & & & & & & & & & & & \\
\hline Dekkera anomala & & & & & & & & 1 & & & & & & & & & & & & & 1 & & & \\
\hline Dekkera bruxelensis & & & & & & & & & & & & & & & & & & 1 & & & & 1 & & \\
\hline Geotrichum fermentans & & & & & & & & & 1 & & & & & & & 1 & & & & 1 & & & & \\
\hline Geotrichum sp. & 1 & & & & 1 & & & 1 & 1 & & 1 & & & & & & & 1 & & 2 & & & 1 & \\
\hline Kluyveromyces lactis & & & & & & 1 & & 1 & & & & & 1 & & 1 & & & & & 1 & & & & \\
\hline Kluyveromyces marxianus & & & & & & & & & & & & & & & & & & & & & & & 1 & \\
\hline Pichia membranifaciens & & & & 1 & & & & & & & & & & & & & & & & & & & & \\
\hline Pichia philogaea & & & & & & & & & & & & & 1 & & & & & & & & & & & \\
\hline Pichia sp. & & & & & & & & & & 1 & & & & 1 & & & & & & & & & & \\
\hline Rhodotorula lactosa & & 1 & & & & & & & & & & & & & & & & & & & & & & \\
\hline Rhodotorula minuta & & & & & 1 & & & & & & & & & & & 1 & & & & & & & 1 & \\
\hline Rhodotorula mucilaginosa & & & & & & & & & & 1 & & & & & & & & 1 & & & 1 & & & \\
\hline Sporidiobolus pararoseus & & & & & & & & & & 1 & & & & & & & & & & & & & & \\
\hline Trichosporon sp. & 1 & & 1 & 1 & & & & 1 & & & & & & & & & & 1 & & & & & & \\
\hline
\end{tabular}




\section{RESULTS}

Eighty strains were isolated from 36 samples obtained from the 25 dairy farms. Yeasts and yeast-like fungi were isolated in most of the samples and presented a great diversity of species (Box 1). There was only one producer from which no strains were isolated (producer number 05). A total of 80 isolates were obtained and identified according to standard methods. Of these, 63 strains corresponded to true yeasts (51 with ascomycetic and 12 with basidiomycetic affinity) and 17 isolates were recognized as yeast-like strains. The isolates were identified in the genera Candida, Cryptococcus, Debaryomyces, Dekkera, Geotrichum, Kluyveromyces, Pichia, Rhodotorula, Sporidiobolus, and Trichosporon. In general, producers sampled more than one time did not show the same yeast species, with the exception of producers number 33 and 37, from which Geotrichum sp. and Candida pararugosa, respectively, were isolated in both sampling times. Although almost $79 \%$ of our isolates were lipolytic, only $6 \%$ were proteolytic.

\section{DISCUSSION}

The scarcity of studies focusing yeasts isolated from raw milk, especially in Brazil, was one of the main motivations for this work. The dairy farms identified as 12, 29 and 37 presented the largest numbers of different species, suggesting that their associated yeast communities are highly diversified. Fifty strains, corresponding to more than $62 \%$ of the total number of isolates, were found in only nine producers $(01,10,12,14,21,29,33,36$, and 37$)$, which represented $36 \%$ of the dairy farms. This emphasizes that the yeast distribution is uneven among the producers analyzed. At present it is not possible to infer if this uneven distribution has any sanitary significance.

The genus Kluyveromyces was found in six producers, representing $7.5 \%$ of the isolates. Kluyveromyces lactis and $K$. marxianus are ascomycetous yeasts commonly isolated from dairy products, and largely employed in biotechnological processes [13]. Species of the genus Rhodotorula represented almost $9 \%$ of the strains, and were the most frequent basidiomycetic yeasts isolated. Rhodotorula mucilaginosa and Rhodotorula minuta are cosmopolitan species, being commonly isolated from several substrates including soil and atmosphere
[1], and their presence in the milk samples may be explained by their dissemination from other substrates.

The 17 yeast-like strains that produced arthroconidia were classified in the genera Geotrichum or Trichosporon. Species that were urease and Diazonium Blue B negative were identified as Geotrichum, while those that were urease and DBB positive as Trichosporon [1]. These strains were isolated from 11 of the 25 producers. As some species of these genera have already been described as human and other animals pathogens, being isolated even from milk of cows with mastitis [7], their high frequency of isolation from raw milk is of great concern.

Four strains of the genus Dekkera were isolated from the producers 12, 29, 34 and 36 . The ability of strong acid production from glucose is one of the most peculiar feature of this genus [11]. The four isolates were capable of producing acid, although in different intensities (data not shown). Dekkera anomala (asexual state Brettanomyces anomalus) and Dekkera bruxellensis (asexual state Brettanomyces bruxellensis) are ascomycetous commonly found in dairy products, fermented beverages and soft drinks, being considered mainly as food spoilage agents [8].

The combined proteolysis and lipolysis of milk constituents by microorganisms have an important impact upon its quality, because they may cause the hydrolysis of the main protein of the milk, the casein, and production of free fatty acids from milk fat, leaving the milk in a gelatinous aspect [4]. The low percentage of caseinolytic strains may reflect the fact that sampling was performed within few hours from milking. As milk is a sterile substrate that is colonized by microorganisms originated from the surrounding substrates (cow, man, churn or the environment), this colonization time was probably too short for allowing competition among microorganisms and predominance of the caseinolytic ones, as could be expected. On the other hand, the high percentage of lipolytic strains in the same conditions emphasizes the fact that colonizing microorganisms may cause alterations in milk constituents since the very beginning of colonization, although it is not possible to infer the significance of these alterations. The presence of lipolytic and proteolytic yeast and yeast-like fungi in milk could favor the growth of other yeast species, since small amounts of free amino acids and fatty acids originating from their enzymatic activity could contribute to the significant growth of other yeasts [15]. 
In summary, it was demonstrated that raw milk samples obtained from several producers in Rio Grande do Sul have a high variety of associated yeasts and yeast-like fungi. Although these microorganisms are not expected to survive the pasteurization/sterilization treatments applied during milk processing, their enzymatic activities may alter milk constituents and affect its quality.

Acknowledgements. The authors thanks Dr. Marisa da Costa for kindly providing the milk samples. This work was supported by PROPESQ/UFRGS (financial support no. 165).

\section{REFERENCES}

barnett J.A., Payne R.W. \& Yarrow D. 2000. Yeast, characteristics and identification. 3rd edn. Cambridge: Cambridge University Press, 1138p.

2 Besancon X., Smet C., Chabalier C., Rivemale M., Reverbel J.P., Ratomahenina R. \& Galzy P. 1992. Study of surface yeast flora of Roquefort cheese. International Journal of Food Microbiology. 17: 9-18.

3 Buzzini P. \& Martini A. 2002. Extracellular enzymatic activity profiles in yeast and yeast-like strains isolated from tropical environments. Journal in Applied Microbiology. 93: 1020-1025.

4 Chen L., Daniel R.M. \& Coolbear T. 2003. Detection and impact of protease and lipase activities in milk and milk powders. International Dairy Journal. 13: 255-275.

5 Cocolin L., Aggio D., Manzano M., Cantoni C. \& Comi G. 2002. An application of PCR-DGGE analysis to profile the yeast populations in raw milk. International Dairy Journal. 12: 407-411.

6 Corbo R.M., Lanciotti R., Albenzio M. \& Sinigaglia M. 2001. Occurrence and characterization of yeasts isolated from milks and dairy products of Apulia region. International Journal of Food Microbiology. 69: 147-152.

7 Costa E.O., Gandra C.R., Pires M.F., Coutinho S.D., Castilho W. \& Teixeira C.M. 1993. Survey of bovine mycotic mastitis in dairy heards in the State of São Paulo, Brazil. Mycopathologia. 124: 13-17.

8 Déak T. 1991. Foodborne yeasts. Advances in Applied Microbiology. 36: 179-278.

9 Ferreira A.D. \& Viljoen B.C. 2003. Yeasts as adjunct starters in matured Cheddar cheese. International Journal of Food Microbiology. 86: 131-140.

10 Fleet G.H. \& Mian M.A. 1987. The occurrence and growth of yeasts in dairy products. International Journal of Food Microbiology. 4: 145-155.

11 Kreger-Van Rij N.J.W. 1984. The Yeasts, a Taxonomic Study. Amsterdam: Elsevier Science Publishers, 1082p.

12 Moreira S.R., Schwan R.F., Carvalho E.P. \& Wheals A.E. 2001. Isolation and identification of yeasts and filamentous fungi from yoghurts in Brazil. Brazilian Journal of Microbiology. 32: 117-122.

13 Querol A., Belloch C., Fernández-Espinar M.T. \& Barrio E. 2003. Molecular evolution in yeast of biotechnological interest. International Microbiology. 6: 201-205.

14 Ravanis S. \& Lewis M.J. 1995. Observation on the effect of raw milk quality on the keeping quality of pasteurized milk. Letters in Applied Microbiology. 20: 164-167.

15 Roostita R. \& Fleet G.H. 1996. Growth of yeasts in milk and associated changes to milk composition. International Journal of Food Microbiology. 31: 205-219.

16 Tempel T. \& Jakobsen M. 1998. Yeasts associated with Danablu. International Dairy Journal. 8: 25-31.

17 Yarrow D. 1998. Methods for the isolation, maintenance, and identification of yeasts. In: Kurtzman C.P. \& Fell J.W. (Eds). The Yeasts. A Taxonomic Study. Amsterdam: Elsevier Science, pp.77-100. 